\title{
Armenian foreign policy between Eurasian and European integration models
}

\author{
Hayk PARONYAN*, Ruben ELAMIRYAN**
}

\begin{abstract}
The article examines foreign policy challenges regarding Armenia's participation in integration models proposed by the EU and Russia, which have changed their role in the contemporary international relations. The discussion focuses on the case study of Armenia to explore how the country is affected by the growing tensions between the EU and Russia and whether it manages to combine two integration models. It argues that growing tensions between the EU and Russia have not allowed Armenia to achieve the Russian-European balance. However, the multi-vector foreign policy strategy allows to maintain and enhance political and economic cooperation with both parties.
\end{abstract}

Keywords: Armenia, foreign policy, integration, EU-Russia competition

\section{Introduction}

The return of geopolitics on the European continent made two aspects apparent. On the one hand, the EU and Russia have entered into a competitive and conflictual relationship with regard to exerting influence on the countries in a number of post-soviet states. On the other hand, the EU main foreign policy strategy towards its eastern neighbours has failed to achieve its objectives of creating peace and stability (Nielsen and Vilson, 2014; Tocci, 2014). The literature is increasingly addressing both aspects. Concerning the former, the increasing assertiveness of Russia, for instance in the launch of the Eurasian Economic Union, the conflicts in the east of Ukraine have spurred the interest in understanding Russia's external behavior, in general, and concerning both the post-soviet space and the EU, in particular (Deyermond, 2016; Donaldson et al., 2015; Tolstrup, 2014).

Concerning the later, it was the former High Representative for Foreign and Security Policy, Federica Mogherini, who acknowledged that the EU's responses to

\footnotetext{
*Hayk PARONYAN is Professor at UNIANDES University of Ecuador, Santo Domingo, Ecuador; e-mail: us.haykparonyan@uniandes.edu.ec.

** Ruben ELAMIRYAN, Head of the Chair of World Politics and International Relations, Russian-Armenian University, Yerevan, Armenia; e-mail: rub.elamiryan @ gmail.com.
} 
recent developments have not been adequate and that it could not serve as a "test case for the EU's foreign policy" (Delcour and Tulmets, 2009). As a consequence, the Commission initiated a critical review of its European Neighbourhood Policy (ENP), including a public consultation on lessons learned and questions on the future direction of the ENP.

One of the areas in which the European Union's foreign and security policy in its neighbourhood is particularly challenged is the South Caucasus. Prevention of conflicts and instabilities in the EU's neighbourhood, building effectively governed and welfare states, as well as safeguarding the energy security of the EU directly or indirectly refers to the region. The region has now gained considerable attention in the framework of the EU's Security policy. The region continues to be fragile and fragmented and the stability and economic development of the South Caucasus countries are increasingly at stake (Paul, 2015).

The South Caucasus has traditionally occupied an important place in regional geopolitics and has been closely associated with the national interests and security of the Russian Empire, the Soviet Union and the Russian Federation. The militarypolitical position of Russia in the region was expressed, in particular, in the signing of a protocol N. 5 with Armenia on the extension of the agreement on Russia's 102nd military base in Gyumri, which Russia has leased rent-free until 2044 (Donaldson et $a l ., 2015)$. Thus, the long-term priorities of Russian politics in the South Caucasus were again at the centre of discussions.

The EU-Russia competition in their common neighbourhood has created obstacles for the countries of the region in the implementation of their multi-vector foreign policy. Not surprisingly, the Armenian government shifted towards the Russia-led EAEU and refrained from joining the Association Agreement (AA) with the EU (Ter-Matevosyan et al., 2017).

From this perspective, the main research question is if it is possible for Armenia to implement its multi-vector foreign policy agenda by developing deep and comprehensive collaboration with the EU while staying and enhancing its presence in the Eurasian Economic Union. Hence, the research hypothesis is that growing tensions between the EU and Russia did not allow Armenia to achieve the Russian-European balance. However, the multi-vector foreign policy strategy allows to maintain and enhance political and economic cooperation with both parties. Additionally, the revision of the EU-Russia relations towards a more cooperative agenda might provide additional room for manoeuvre for Armenia.

Previous researchers had focused on the different aspects of the Armenian interaction with Russia and the EU: Delcour and Wolczuk (2015) described the geopolitical circumstances that made the Armenian government sign up to the Eurasian Economic Union; Kostanyan and Giragosian (2017) dedicated their works to the analysis of the relations between Armenia and the EU after signing the EUArmenia Comprehensive and Enhanced Partnership Agreement (CEPA); Terzyan (2019) described the challenges to the EU-Armenia CEPA implementation; Roberts 
and Moshes (2016) explored EAEU's ability to make a significant impact in the postSoviet space to achieve deep integration; Vasilyan (2017) considers the challenges of being a member of the EAEU and the repercussions on the country's relations with the EU; Ter-Matevosyan et al., (2017) examines the political and economic implications of Armenia's EAEU membership, providing a number of explanations for that political decision, etc. The current paper focuses on potential possibilities for Armenia to achieve the Russian-European balance and to explore whether the multivector foreign policy can survive in times of raising great power competition.

To test the hypothesis and answer the research question, the article is based on synthesis methods of analysis from a qualitative research perspective starting with a session dedicated to Armenia's main foreign policy vectors and strategic priorities. It continues with the discussion of Armenia's participation in the EAEU, its main motives and rationale beyond the strategic shift in 2013. It argues that, despite the fact that Armenia did not sign the Association Agreement back in November 2013 during the Eastern Partnership Summit in Vilnius and joined the EAEU in 2015, it continued to gradually strengthen its relations with the EU.

In order to gain a better insight into the possibilities to combine two opposing integration models, to explore the multi-vector foreign policy perspectives in times of raising great power competition, semi-structured expert interviews were conducted with a number of leading international experts. Additionally, the article presents the fluctuations of economic cooperation in the Armenia-EU-Russia triangle. It discusses such indicators as trade and foreign direct investments, as well as the EU foreign aid. This allows understanding the essence and room for manoeuvre for Armenia not only in political and geopolitical terms, but also in terms of the economic rationale beyond the current state of affairs. Furthermore, the article comes up with a discussion on the room for manoeuvre for Armenia provided, on the one hand, the rising global uncertainty and major power competition, on the other.

\section{The main directions of Armenia's foreign policy}

After the collapse of the Soviet Union, the former Soviet republics faced the need to define their new role in international relations. The construction and development of the sovereign national-state institutions have been influenced by many factors, such as economic and geographical conditions, relations with neighbouring states, etc. (Kolstø and Høivik, 2018).

The formation of the Armenian statehood took place in difficult economic and political conditions: on the one hand, Armenia has made efforts to establish itself, with a faltering economy and growing emigration of skilled human resources. On the other hand, the newly created republic faced the most difficult problems of the transition period along with the blockade of communication routes by Azerbaijan and Turkey. In the formation of its foreign policy, the leadership of the Republic of 
Armenia was forced to take into account various factors and threats to the national security of the country (Giragosian, 2014).

Two important principles have shaped the Armenian foreign policy in the past decade: efforts to normalise relations with neighbouring countries and the desire to integrate independent Armenia into the international community. Since the first days of its independence, Armenia has been making an active effort to enhance its political and economic integration to the world community. Since 1992, it has been a member of the UN and the OSCE, and since 2001 - the Council of Europe, it has been actively participating in the activities of these organisations. Armenia is a member of the CIS (Commonwealth of Independent States, since December 21, 1991) and CSTO (Collective Security Treaty Organisation). In the beginning of 2003, Armenia also became a full member of the World Trade Organisation (WTO), which ensured the republic's entry into a new field of international legal obligations, trade and economic relations.

The development of foreign policy was greatly influenced by the active involvement of non-regional actors in the political processes in the South Caucasus. In such circumstances the leadership of Armenia developed the "National Security Strategy" and the "Military Doctrine" (2007), as conceptual bases of the republic's foreign policy. In the implementation of its external security strategy, Armenia is guided by the following main principles: multi-vector foreign policy - establishment of mutually beneficial partnership relations with all stakeholders in the region, aimed at maintaining a balance between various external forces; involvement (integration) - Armenia's involvement in regional and global integration processes. The strategic partnership with Russia, mutually beneficial cooperation with the EU and Iran, membership in the CSTO, development of cooperation with NATO expanded the potential for implementing a multi-vector foreign policy.

Given the complex geopolitical situation in the South Caucasus, the Armenian authorities have pursued a balanced foreign policy. In its relations with NATO, Armenia shows flexibility, striving to build them in the light of the objectives of military-political cooperation with Russia. Starting from 2002, Armenia participates in the NATO Partnership for Peace program, and since 2005 - in the Individual Partnership Action Plans project, which helps Armenia strengthen the country's armed forces. Additionally, Armenia contributes to the NATO-led operations in Afghanistan (since 2009) and Kosovo (since 2004 - NATO 2020). The so-called "complementarism" (multi-vector foreign policy) became the main foreign policy concept of Armenia. The essence of this concept was to maintain a balance between the interests of regional and world actors involved in the political processes of the South Caucasus region (Minasyan, 2012).

One of the priorities of the Armenian foreign policy is to enhance the economic cooperation with the EU in order to integrate with European structures (Gomółka, 2017). Since 2004, Armenia has participated in the EU's program European Neighbourhood Policy, and since 2009 - in the program of cooperation 
between the EU and six former Soviet countries - the Eastern Partnership. The multivector policy foreign policy has been associated with the name of the second president of Armenia, R. Kocharyan. However, such a foreign policy was characteristic of the policy of the presidents of Armenia L. Ter-Petrosyan and S. Sargsyan, as well as for the foreign policy course of the current Armenian Prime Minister, N. Pashinyan.

Multi-vector foreign policy continues to be implemented by the Armenian government despite constant accusations of practical insolvency or the imminent end of the policy. In fact, the foreign policy doctrine of Armenia could equally be called pragmatism or realism. Nowadays, the Armenian foreign policy seeks to unite the conflicting interests of Russia and the West.

On the other hand, the great power politics rising globally and in the South Caucasus, particularly, make it more complex for Armenia to pursue the multi-vector foreign policy and find a balance between the major powers. According to Eric Brown, senior fellow at Hudson Institute:

A country like Armenia, which is situated directly in the centre of this big geopolitical turnings needs to aspire to try to find some concept among the larger geopolitical giants, that surround Armenia and a number of other countries in the region and elsewhere" (expert interview conducted by R. Elamiryan, 2019).

Brown thinks that, in addition to creating a culture of cooperation among those centres of power or some of them, to balance them against one another, it is also vital for Armenia to build close cooperation with the countries that face a very similar situation. According to him, that includes not only the countries which are directly in the region but also subnational polities like the Kurds, particularly, in Northern Iraq.

At the same time, Dr. Jeffrey Mankoff, who is a Deputy Director and Senior Fellow at the CSIS Russia and Eurasia Program, thinks that the small countries in the region should try and make sure not to go one way or another but to pursue their own national interests. According to him, Pashinyan in Armenia tries really to do this by making it clear that the revolution is not about decreasing Russian influence, challenging Russia's positions in the country or becoming part of NATO, but about internal Armenian problems - corruption, Armenian government and all the rest. However, according to Mankoff, for a country that has more flexibility than Armenia, that is harder to achieve because every new election, every new decision is going to be perceived as moving this or that way. He considers that the lesson for these countries should be trying to avoid making themselves an object of these geopolitical struggles (expert interview conducted by R. Elamiryan, 2019).

On the other hand, Dr. Celeste Wallander (CEO of the U.S.-Russia Foundation), Matthew Rojansky (the Director of the Wilson Center's Kennan Institute), and Steven Blockmans (a senior research fellow and the Head of the "EU foreign policy" and "Politics and Institutions" units of Centre for European Policy 
Studies) have a more pessimistic view about Armenia's potential to balance between the major powers. For instance, Wallander thinks that a more peaceful agenda between the major powers in the region is impossible: "it could work if you reject your own national interests" (expert interview conducted by R. Elamiryan, 2019).

In answering the question about what the countries in the region can do to decrease the conflictual developments at least on their territories, Rojansky stated:

There is nothing, unfortunately. Of course, if Armenia and Azerbaijan suddenly solve this three-decades old conflict, that could be something also. But these things are most likely not going to happen. As long as this basic conflict dynamics remains, it is not going to make any difference, because the fundamental conflict dynamics that is going on, the fundamental distrust is beyond the capacity (expert interview conducted by R. Elamiryan, 2019).

Finally, Blockmans thinks that there is some potential for the EaP countries to foster a peace-oriented agenda in the region, but the outcome should not be overestimated (expert interview conducted by R. Elamiryan, 2019).

On the other hand, Dr. Irina Bolgova, an associate professor at the Department of Applied Analysis at Moscow State Institute of International Relations (MGIMO) has a more positive view on the potential for the multi-vector foreign policy for the countries of the region and Armenia, particularly. Answering the question if she thinks that the rising Russia-West animosity will make the countries of the region choose only one side to develop friendship with, she answered that, according to her, it is no longer the case after the Ukrainian crisis of 2013-2014 and its consequences (expert interview conducted by R. Elamiryan, 2019). Thus, given the increasing power competition, we see a rather diverse set of opinions on the potential to implement the multi-vector foreign policy for small and medium-size countries.

\subsection{Armenia's shift towards the Eurasian Economic Union}

Armenia's official position in relations with the European Union has been using the rhetoric of a common European identity and the desire to promote the idea of European integration as a civilisational choice of the country. The former Armenian President, Serzh Sargsyan, repeatedly stressed that the Armenian people is an inseparable part of Europe, which determines the bases of Armenia's foreign policy towards European integration. At the same time, there was a tendency in the foreign policy discourse to view the EU as a normative player that can use systems of "soft" instruments to solve "hard" problems in the South Caucasus (Bolgova, 2016).

Such an emphasis in the official rhetoric persisted until 2013. With the beginning of the Ukraine crisis, it became obvious that there are many difficulties in the implementation of a balanced foreign policy. After the decision to enter the Eurasian Economic Union, motivated by security and economic factors, the country's 
leadership began to speak out against existing cooperation programs with the EU, critically emphasizing the instability and lack of cooperative arrangements among the states-participants of the Eastern Partnership, their goals and approaches, which did not allow implementing multilateral cooperation within the framework of the program.

Armenia has taken the path of entry into the EAEU with the simultaneous development of new forms of rapprochement with the EU; and this way is perceived in Yerevan as an opportunity to combine the civilisational choice made centuries ago (Europe) and pragmatic interests in the sphere of economy and security (Russia). The cooperation with Russia is an important element of Armenia's foreign and defence policy. According to the Treaty of 1995, both countries have obligations for mutual defines and assistance. The 102nd Russian military base is deployed in Armenia; Armenia is an active member of the CSTO - a military-political bloc under the aegis of Russia. Russia is also the main investor in the Armenian economy and, despite the absence of direct geographical connection, closely cooperates with Armenia in the energy and communication fields.

Considering these circumstances, Armenian leadership preferred to join to the Russian-led Eurasian Union. The decision has been interpreted in many different ways. The European leaders reacted critically, considering that the Russia-led Customs Union and the DCFTA with the EU are not compatible. It has given rise to the prevailing opinion that Armenia's decision was made under Russian pressure and blackmailing (Ter-Matevosyan et al., 2017). According to Cornell (2014), the creation of the Eastern Partnership has intensified the forceful promotion of the Eurasian Union project by V. Putin, because the EU's "soft power" initiative was interpreted by Kremlin as an attempt of the EU to create a "sphere of influence".

In recent years, the criticism concerning Armenia's membership in the EAEU has been intensified in political and non-governmental circles. According to Terzyan, (2017), closer scrutiny of external constraints indicates that Russian coercive policy left little room for Armenia to achieve a Russian-European balance. In particular, according to this critic, EAEU is more needed by Russia and Kazakhstan than by Armenia and the entry of the country into the EAEU at the beginning of 2015 did not lead to significant positive economic consequences, which was associated with both the global economic crisis and the sanctions against Russia.

On the other hand, Armenia's EAEU membership allowed the country to avoid security challenges connected with the import of oil and gas from Russia, free movement of labour force, and access to the Russian market. If we turn to some figures, it can be noted, for example, that, after its entry into the EAEU, Armenia was expected to receive $1.13 \%$ of the total customs duties of the association, as provided by the terms of the organisation, to incur significant costs as a result of trade diversion after joining the EAEU (Petrov and Van Elsuwege, 2017). However, by mid-2015, it became clear that, with the fall in oil prices, sanctions and the 
economic recession in Russia, the economic gains associated with the EAEU would be much more modest.

In response to Western sanctions, Russia restricted the import of goods from countries that imposed sanctions on it, thereby opening up new opportunities for the countries of the EAEU to increase exports to Russia. However, it is impossible not to notice such an important factor hindering the process of full integration of Armenia into the Eurasian Union: the lack of borders with other countries of the Eurasian Union (Babayan, 2017).

In September 2015, Armenia initiated the creation of a free trade zone between the countries of the Eurasian Economic Union and Iran, inviting the Eurasian Economic Commission to begin this process. It is important to note that Armenia is the only member state of the Eurasian Union which has a land border with Iran. As a member of the Eurasian Economic Union Armenia can play an important role for Iran as a link and a starting platform in the economic integration of Iran and the countries of the Eurasian Economic Union. It should be noted that more than 40 countries and international organisations have expressed a desire to create a free trade zone with the Eurasian Economic Union, including Indonesia, China, Thailand and Cambodia. Today, there is a free trade zone with Vietnam.

\section{Armenia-EU-Russia: towards the economic complementarity}

Despite Armenia's participation in the Eurasian Economic Union (EAEU), the government has been determined to expand its relations with the EU. The new stage of relations formally opened by the signing of The Comprehensive \& Enhanced Partnership Agreement between the European Union \& Armenia, which demonstrated a fresh start for deepening the relations between the two parties (Kostanyan and Giragosian, 2017). For the European Union, this was a search for a way out of the crisis of the Eastern policy, for Armenia, it was the pursuit of a multivector policy in the conditions of existing structural limitations.

On the one hand, Brussels has developed a new type of normative document, complementary to the EAEU after the decision of Yerevan not to initial the negotiated Association Agreement with the EU, including a Deep and Comprehensive Free Trade Area (AA/DCFTA). On the other hand, for the first time during the functioning of the Eurasian Economic Union, one of its member states signed an agreement of this magnitude with another integration association. As a result, a new stage in the negotiation processes between Armenia and the EU for both sides has become simultaneously a pilot project on combining integration projects in the post-Soviet space and testing the possibility for the EAEU member state to pursue an independent foreign economic policy.

The main question is how the new political relations between Yerevan and Brussels can contribute to the formation of a new model of complementarity of integration projects in the Eurasian political space. In October 2014, one year after 
Yerevan's decision to refuse to sign the Association Agreement in favour of joining the EAEU, the European Union initiated a detailed analysis of areas where it is possible to combine Armenia's participation in the EAEU and deepen cooperation with the EU. As a result of this work, on December 7, 2015, negotiations began on a new framework agreement, thus completing a "strategic pause" in relations between the EU and Armenia. The new document was initialled and signed in November 2017.

The content of the CEPA reflects the desire of the Armenian political elites to maintain a special position in relations with both the EU, Russia and the EAEU. It retains a large volume of text prepared in the framework of the negotiations on Association Agreement, primarily in terms of political dialogue and security issues. The CEPA is considered as a breakthrough in the relations between the EU and Armenia, as it represents the first successful example of a realistic and pragmatic approach by the EU to the Eastern Partnership states, based on specific conditions and constraints. At the same time, for Armenia, the Agreement is the result of the recognition of the foreign policy choice of its political elites, which seek to deepen relations with the EU, despite the recognition of reliance on Russia in matters of national security (Dragneva, 2017).

The CEPA includes all the main articles envisaged for the AA, but the depth of elaboration and the corresponding obligations depends on the limitations imposed by the EAEU membership. The text of the Agreement underscores the recognition of Armenia's obligations within the framework of the EAEU, including those restrictions that prevented reaching an agreement on an in-depth free trade zone, which was the main innovation in the Eastern policy of the European Union. The section of the political dialogue repeated the relevant articles of the AA, not because of the absence of contradictions in this sphere between the relations of the EU and the EAEU, but in connection with its predominantly declarative nature. In this area, there are no legally binding provisions, so the negotiations passed without any difficulty (Kostanyan and Giragosian, 2017).

The CEPA does not mention Armenia's commitments to its "European aspirations", but there are references to general international agreements (the UN Universal Declaration of Human Rights and the European Convention on Human Rights and Fundamental Freedoms), according to which the parties declare adherence to common values, such as democracy, good governance, human rights, the protection of minority rights, the independence of the judiciary and other fundamental freedoms.

The agreement promotes the cooperation between the EU and Armenia in the field of the Common Security and Defence Policy (CSDP). Yerevan intends to strengthen its participation in relevant European missions. Armenia has already taken part in the common operations of the UN and NATO and, after signing the Agreement with the EU, this opportunity opens up for European formats. First of all, Yerevan's desire to be included in the cooperation in the framework of the CSDP 
was caused by the desire to receive technical assistance in the country's transition to a parliamentary republic process.

Nevertheless, cooperation in the field of common security remains primarily in the form of declarations of the desire to strengthen dialogue and cooperation and recognise the importance of Armenia's participation in international organisations. This reflects a significant decrease in the level of interaction in comparison with the EU-Ukraine Association Agreement, where gradual convergence was envisaged in the field of foreign and security policy (Van der Loo, 2018).

The topics included in the Agreement on cooperation in the field of security also raises issues of legal and illegal migration, border control, asylum and general principles of citizens' movement. Nowadays, the process of visa liberalisation is among the urgent issues for Armenia. An agreement between Armenia and the EU in this field was signed and entered into force in January 2014. In September 2016, the Armenian Foreign Ministry filed an official request to open a dialogue on visa liberalisation but did not receive consent. Armenia carried out reforms within the framework of the visa liberalisation process while preparing to sign the Association Agreement. After the decision to join the Eurasian Economic Union, issues related to visa liberalisation remained on the agenda of Armenia-EU relations. Brussels continues to provide financial assistance for carrying out reforms in the framework of the visa dialogue.

Negotiations on the new agreement brought the issue of the Armenian nuclear power plant (NPP) in Metsamor on the agenda. Today, Armenia does not have the opportunity to concede to the requirements of the EU to shut down the nuclear power plant, as it was previously decided to extend its service life to 2026.

It should be recalled that, in 2001, the EU promised to invest up to 100 million euros for the closure of the nuclear power plant in the case of an agreement with a fixed date. In 2012, the EU conducted stress tests in Armenia (after the Fukushima accident) and offered 200 million euros to finance the closure by 2016. In 2014, Russia and Armenia signed an intergovernmental agreement on cooperation in extending the life of the power unit No. 2 Armenian NPP, which provides for the modernisation of the plant and the extension of its service life to 2026. In this context, the CEPA stipulates the commitment of the Armenian government to prepare a road map for decommissioning the nuclear power plant. The plot of the Metsamor NPP is important not only for the bilateral relations between Armenia and the EU, but in the broader context of Armenia's energy security. However, the abandonment of nuclear power plants may reduce the level of the country's energy self-sufficiency.

The prospects for economic cooperation between Armenia and the EU remain the most acute topic, both within the framework of the new Agreement and in the wider context of the relations between the EU, Armenia and the EAEU. The CEPA does not provide for an in-depth or simple free trade zone between Armenia and the EU in connection with the membership of Yerevan in the Eurasian Economic Union. 
Since all the trade competencies of the EAEU member states are transferred to the Eurasian Economic Commission level, in the relations between Yerevan and Brussels, there was no question on tariffs liberalisation. At the same time, Armenia remains a member of the World Customs Organisation and will continue to monitor compliance of its tariff obligations with the WTO and the EAEU.

Armenia's exports to the EU are currently implemented within the framework of the generalised system of preferences (GSP+). Under this system, Armenia has the right to export about 6,400 trade positions to the European Union at zero or reduced tariffs (Tumasyan et al., 2018). Seeking to integrate into the international trade, the European scheme (GSP +) aims at economic cooperation with countries that have difficulties in diversifying their foreign trade.

Armenia is running rather effective multi-vector or complimentary foreign economic policy, continuing comprehensive economic cooperation with the EU even after becoming an EAEU member. At the same time, neither the EU, nor Russia obviously limit their own cooperation with Armenia because of the other side, establishing a platform for mutually beneficial cooperation for all the involved sides. Figures 1-3 demonstrate that:

1. Both the EU and Russia have a major share in Armenia's economy, which was the case during the whole discussed period.

2. There is a steady rise of both the EU and Russia's share in Armenia's export, with some drop for both the EU and Russia. As a consequence, this decline can be reasoned by Armenia's domestic economic situation.

3. In the case of import, Figure 2 demonstrates that, with the launch of the EAEU, the share of the EU's export to Armenia dropped to the level of 2009, while Russia's export to Armenia faced constant rise.

4. In terms of the FDIs, we do not see any clear evidence of the EAEU's impact on the EU's investments to Armenia. On the contrary, from 2009 until 2017, there is a significant drop of Russian FDIs (almost two times), while the FDIs from the EU have almost doubled.

5. At the same time, there is a rise of the EU foreign aid from approximately 90 $\mathrm{mln}$ USD in 2009 to almost $250 \mathrm{mln}$ USD in 2016 (see figure 4). Additionally, the European Union's assistance to Armenia from 2017 to 2020 will amount to 176 million euros ( $\$ 208$ million) as a result of a landmark agreement signed by Armenia and the EU in November, 2017 (Arka News Agency, 2018). 


\section{Figure 1. Export (share, in \%)}

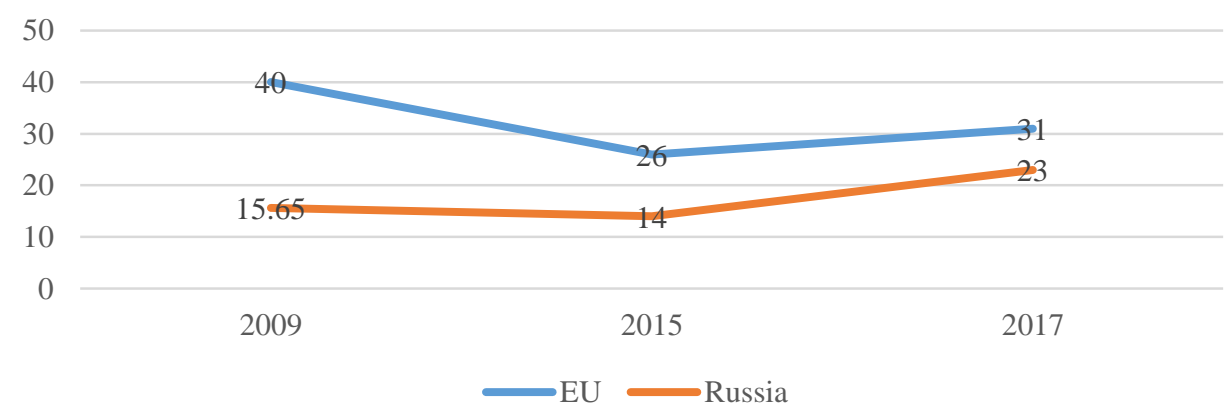

Source: Authors' representation

Figure 2. Import (share, in \%)

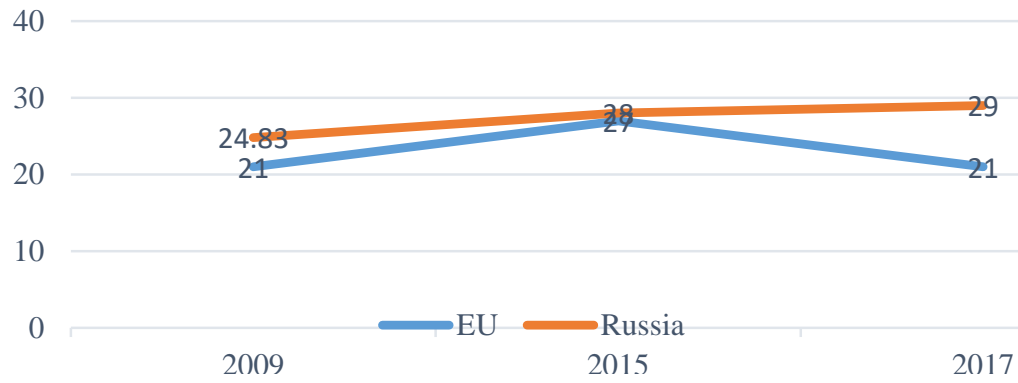

Source: Authors' representation

Figure 3. FDI (in mln USD)

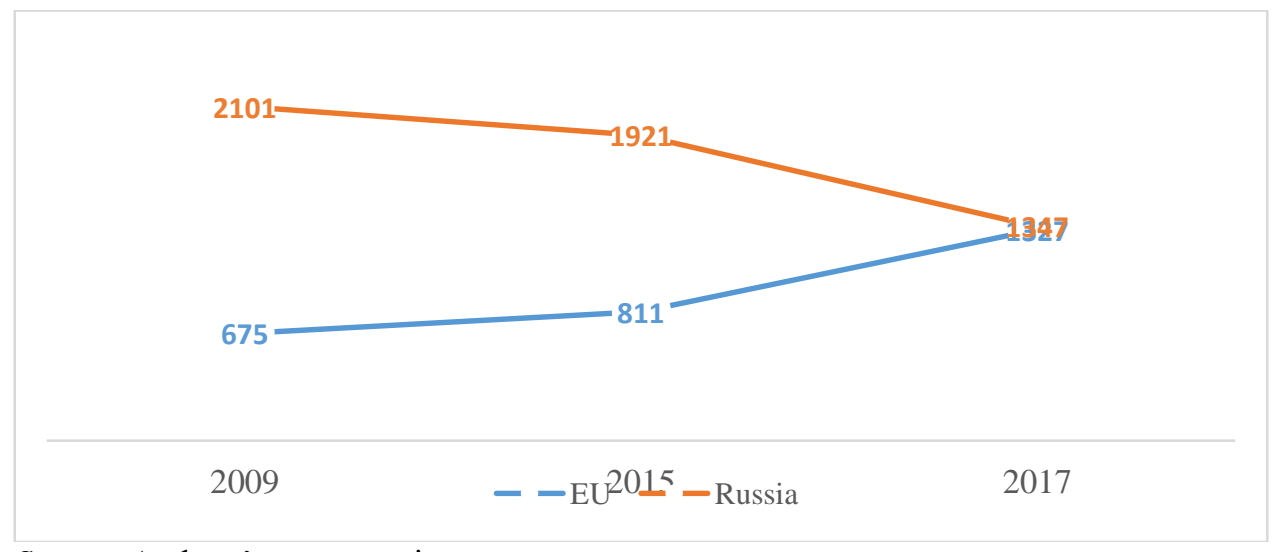

Source: Authors' representation 
Figure 4. EU Foreign Aid/per country in mln USD

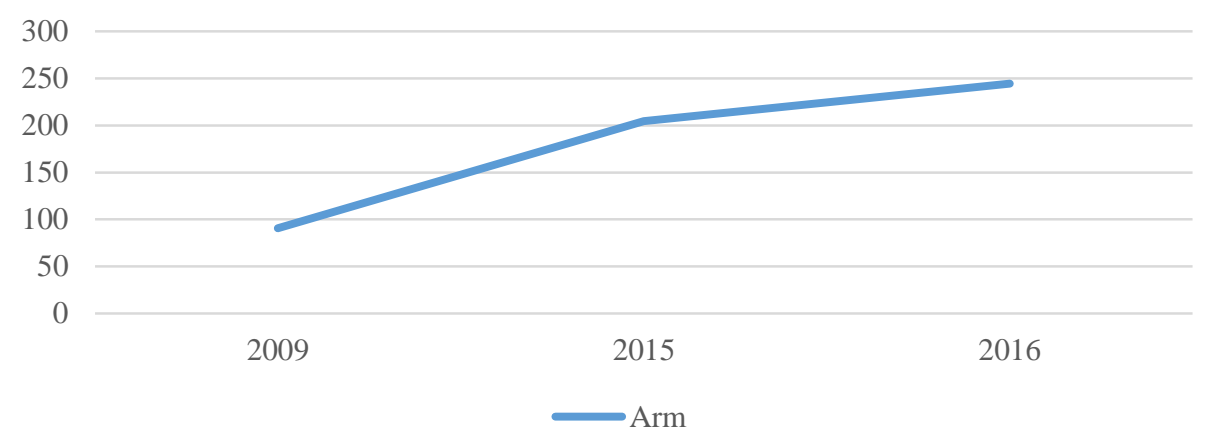

Sources: Atlas Media, World Bank, International Monetary Fund

\subsection{Can the multi-vector foreign policy survive in times of increasing power competition?}

There is no single approach towards the understanding and, what is more important in this case, explanation and prediction of the potential future of Armenia's multi-vector foreign policy. Additionally, the current turbulence and uncertainty in international relations contributes to speculations around this issue. The history of the last eleven years with Armenia's strategic balancing between its EAEU membership and effective participation in the EaP demonstrates the opportunities for multi-vector foreign policy and serving as a hub for the development of positive collaboration (Elamiryan, 2017). However, the increasing power competition in the world develops the fear of its replication towards the Eastern Partnership region, South Caucasus and particularly Armenia, narrowing down its room for manoeuvre and implementation of complementary foreign policy.

In this context, the following expert interviews are called to bring more clarity into this discussion. In talking about the opportunities for EaP countries and specifically, Armenia, in an expert interview, Mankoff put it this way:

Even though the relations between West and Russia get worse, as it seems to be, it is going to force these countries more and more in the position when they have to make a choice. For Georgia, Ukraine, Armenia, and Belarus, it is pretty much clear what it is going to look like, for Azerbaijan - they are going to try to do this multi-vector thing as long as they can and it depends on how skilful their diplomats and politicians are (expert interview conducted by R. Elamiryan, 2019).

According to him, the increasing power competition is going to force the EaP countries more and more in the position when they will have to make hard choices. At the same time, in answering the question if she thinks that the rising Russia-West 
confrontation will make the EaP countries face a hard choice on the side they belong to, Wallander answered that she has the feeling that the analysis is right:

Today, more and more foreign policy decision-makers look at countries through "Russia lenses", which means how tough you are on Russia, as the US is getting more hostile to Russia. At the same time, Kremlin plays the zerosum game, especially after the Bolotnaya protests (expert interview conducted by R. Elamiryan, 2019).

Additionally, she clarifies that, according to her, for instance, the sides agreed on the current Armenia-EU agreement as the Armenian economy is small and not essential for them.

Finally, Bolgova expresses more optimism with regard to the potential collaboration between the West and Russia in Armenia and the Eastern partnership region, in general. In answering the question about the opportunities to develop a culture of collaboration in the EaP region so as to establish a platform of equal opportunities for all the global actors, including the EU and Russia, Bolgova said that there is no evident answer on the surface:

The June crisis in Moldova, in which Russia, the EU, and the US took part to resolute it, signals that yes. However, this is a crisis response. Meanwhile, long-term interaction demands unified principles of "equal opportunities". This is a complicated task, if not impossible (expert interview conducted by R. Elamiryan, 2019).

According to her, in terms of the general decline of interest, there could be a formalisation of cooperation when, for instance, in the case of Armenia, joint "European" and "Chinese" parts of the same highway are being built by different standards and almost different routes though it is presented as a joint project. Additionally, Bolgova clarified that, according to her, Russia expects the EU to become more cooperative with Russia in face of the Chinese rise and its movement towards the West.

The range of the above opinions clearly demonstrates the complexity and multilayer nature of the issue. However, it can be argued that Armenia clearly has a successful history and future potential to develop its multi-vector foreign policy with both the EU and Russia, provided that it will continue to play a fair, transparent, and "open game" with its partners. On the other hand, the outbreak and results of the Second Artsakh war has significantly changed the geopolitical environment in the South Caucasus with a potential to impact the current foreign policy priorities of Armenia.

Particularly, on September 27, 2020, with Turkish support, the Armed Forces of Azerbaijan, launched a large-scale military offensive against the de-facto independent Nagorno-Karabakh Republic (called Artsakh in Armenian), an area inhabited and governed by ethnic Armenians and supported by the Republic of 
Armenia. The ensuing war continued for 44 days, and ended with thousands of casualties and Azerbaijani forces controlling much of Nagorno-Karabakh (Avetikyan, 2020). On November 10, 2020, Russian President Vladimir Putin brokered a ceasefire statement between Prime Minister of Armenia, N. Pashinyan, and President of Azerbaijan, Ilham Aliyev, outlining terms for territorial transfers, returns of displaced people, and the deployment of a Russian peacekeeping forces (Ministry of Foreign Affairs of the Russian Federation, 2020).

For years, based on soft-power tools and economic cooperation, the EU has been empowering and developing its cooperation with Armenia. Neither before, nor after the Second Artsakh war, has the EU ever directly participated in one of the main foreign policy and security issue for Armenia - Nagorno-Karabakh conflict, by relying on the OSCE mechanisms. Additionally, the EU has indirect participation in the peace talks with France as an OSCE Minsk Group Co-Chair, along with the USA and Russia.

Currently, with its peacekeepers on the ground, Russia is the main security guarantor for Armenians in Artsakh. Moreover, with the growing Azerbaijani ambitions over Armenia's region of Syunik and support coming from the Turkish President Erdogan, Russia is also the main security guarantor of the territorial integrity of the Republic of Armenia (Russian military in Armenia reinforce areas near Azeri border).

The above does not mean that Russia is going to restrict the European vector of Armenia's foreign policy. However, if the relations between the EU and Russia get worse, Moscow will likely use the existing leverages over Armenia to restrict its ties with the EU. At the same time, given the interest and necessity for strategic stability in their neighbourhood, the consequences of Georgian and Ukrainian conflicts, the rising challenges to global security, as well as the complementary interest to restrict Turkey's and China's presence in Armenia and South Caucasus, both the EU and Russia are interested to develop a positive collaboration agenda in Armenia, not impeding the latter to continue to develop the current level of multivector foreign policy.

\section{Conclusions}

Despite the further deepening of the military-political and economic ties with Russia and being a member-state of the EAEU, Armenia aims at expanding its cooperation scope with the EU. The leadership of the country has emphasised the desire to bring the national legislation closer to European standards in areas that are out of the competence of the EAEU regulation. Under such circumstances, Armenia seeks to increase its economic autonomy and maximise the relations with the European Union. Such a policy allows to maintain and develop close political and economic relations with the EU.

Russia's role in brokering the ceasefire has significantly increased its influence over Armenia and South Caucasus, in general. However, the current 
developments in the Nagorno-Karabakh conflict will hardly have a direct impact on the Armenia-EU relations. The European Union has proved the priority of the postSoviet space on its political agenda, demonstrating that the Eastern Partnership is not an anti-Russian project aimed at undermining Russia's geopolitical and economic interests but a project aimed at supporting its eastern partners to promote political and economic reforms to ensure security, stability, democracy and rule of law in Eastern Europe and in the Southern Caucasus region.

Acknowledgments: A draft of this article was presented at the 19th Annual Conference of CESS, held at the University of Pittsburgh on October 25-28, 2018. The authors are grateful to the National Association for Armenian Studies and Research (NAASR), Knights of Vartan Fund for Armenian Studies for their support, as well as to the editor of this journal and the anonymous reviewers for their in-depth comments.

\section{References}

Arka News Agency (2018), Armenia to receive 176 million euro assistance from European Union for 2017-2020 (retrieved from http://arka.am/en/news/politics/ armenia_to_receive_176_million_euro_assistance_from_european_union_for_2017_2 020/).

Avetikyan, G. (2020), The 2020 war in Nagorno-Karabakh: the regional dimension, Pathways to Peace and Security. https://doi.org/10.20542/2307-1494-2020-2-181-191.

Babayan, N. (2017), Democracy Promotion and the Challenges of Illiberal Regional Powers, in: Babayan, N. and Risse, T. (eds.), Democracy Promotion and the Challenges of Illiberal Regional Powers, Routledge, pp. 1-19. https://doi.org/10.4324/9781315623160.

Bolgova, I. (2016), "Eastern partnership": Ambiguous results, Sovremennaya Evropa, (6), pp. 63-71. https://doi.org/10.15211/soveurope620166371.

Cornell, S.E. (2014), Underestimating Yourself: The EU and the Political Realities of the Eastern Neighbourhood, European View, 13(1), pp. 115-123. https://doi.org/10.1007/s12290-014-0300-z.

Delcour, L. and Tulmets, E. (2009), Pioneer Europe? The ENP as a test case for EU's foreign policy, European Foreign Affairs Review, 14(4), pp. 501-523.

Delcour, L. and Wolczuk, K. (2015), The EU's Unexpected 'Ideal Neighbour'? The Perplexing Case of Armenia's Europeanisation, Journal of European Integration, 37(4), pp. 491507. https://doi.org/10.1080/07036337.2015.1004631.

Deyermond, R. (2016), The Uses of Sovereignty in Twenty-first Century Russian Foreign Policy, Europe - Asia Studies, 68(6), pp. 957-984. https://doi.org/10.1080/09668136.2016.1204985. 
Donaldson, R.H., Nogee, J.L. and Nadkarni, V. (2015), The Foreign Policy of Russia: Changing Systems, in: Donaldson, R.H. and Nadkarni, V. (eds.), Enduring Interests, New York: ME Sharpe. https://doi.org/10.1017/CBO9781107415324.004.

Dragneva, R. (2017), The Eurasian Economic Union: Balancing sovereignty and integration, in: Petrov, R. and Van Elsuwege, P. (eds.), Post-Soviet Constitutions and Challenges of Regional Integration: Adapting to European and Eurasian Integration Projects. https://doi.org/10.4324/9781315656847.

Elamiryan, R. (2017), Eastern Partnership Countries on the Crossroads of the Eurasian Integration Processes, Institute for Foreign Affairs and Trade (retrieved from https://www.researchgate.net/).

Giragosian, R. (2014), Armenia's search for independence, Current History, 113(765), p. 284. https://doi.org/10.1525/curh.2014.113.765.284.

Gomółka, K. (2017), Threats to Armenia’s Security in the National Strategy and Practice with Special Emphasis on External Security, Polish Political Science Yearbook, 46(1), pp. 74-90. https://doi.org/10.15804/ppsy2017105.

Kolstø, P. and Høivik, S. (2018), Political construction sites: Nation-building in Russia and the Post-Soviet states, in: Kolsto, P. (ed.), Political Construction Sites: Nation Building in Russia and the Post-Soviet States. https://doi.org/10.4324/9780429498220.

Kostanyan, H. and Giragosian, R. (2017), EU-Armenian Relations: Charting a Fresh Course Title, CEPS Research Report, 14.

Minasyan, S. (2012), Multi-vectorism in the foreign policy of post-soviet eurasian states, Demokratizatsiya, 20(3), p. 268.

Nielsen, K.L. and Vilson, M. (2014), The Eastern partnership: Soft power strategy or policy failure?, European Foreign Affairs Review, 19(2).

Paul, A. (2015), The EU in the South Caucasus and the Impact of the Russia-Ukraine War, International Spectator, 50(3), pp. 30-42. https://doi.org/10.1080/03932729. 2015.1054223.

Petrov, R. and Van Elsuwege, P. (2017), Post-soviet constitutions and challenges of regional integration: Adapting to European and Eurasian integration projects, in: Petrov, R. and Van Elsuwege, P. (eds.), Post-Soviet Constitutions and Challenges of Regional Integration: Adapting to European and Eurasian Integration Projects, Routledge. https://doi.org/10.4324/9781315656847.

Roberts, S.P. and Moshes, A. (2016), The Eurasian Economic Union: a case of reproductive integration?, Post-Soviet Affairs, 32(6), pp. 542-565. https://doi.org/10.1080/ 1060586X.2015.1115198.

Ter-Matevosyan, V., Drnoian, A., Mkrtchyan, N. and Yepremyan, T. (2017), Armenia in the Eurasian Economic Union: Reasons for joining and its consequences, Eurasian Geography and Economics, 58(3), pp. 340-360. https://doi.org/10.1080/ 15387216.2017.1360193.

Terzyan, A. (2017), The EU vs. Russia in the foreign policy discourse of Armenia: The fragility of normative power or the power of Russian coercion?, Eastern Journal of European Studies, 8(2), pp. 185-203. 
Terzyan, A. (2019), Bringing Armenia closer to Europe? Challenges to the EU-Armenia comprehensive and enhanced partnership agreement implementation, Romanian Journal of European Affairs, 19(1), pp. 97-110.

The Ministry of Foreign Affairs of Russian Federation (2020), Statement by the President of the Republic of Azerbaijan, the Prime Minister of the Republic of Armenia and the President of the Russian Federation, 10 November.

Tocci, N. (2014), The Neighbourhood Policy is Dead. What's Next for European Foreign Policy Along its Arc of Instability?, Istituto Affari Internazionali.

Tolstrup, J. (2014), Russia vs. the EU: The Competition for Influence in post-soviet states, in: Published in 2014 in Boulder Colo) by First Forum Press. Boulder (Colo.): First Forum Press.

Tumasyan, M., Harutyunyan, K., Manukyan, Y. and Grigorian, A. (2018), EU-Armenia Trade Liberalization: A Poverty and Social Impact Analysis, SSRN Electronic Journal. https://doi.org/10.2139/ssrn.3167965.

Van der Loo, G. (2018), The EU-Ukraine Deep and Comprehensive Free Trade Area, in: Van Elsuwege, P. and Petrov, R. (eds.), Legislative Approximation and Application of EU Law in the Eastern Neighbourhood of the European Union. https://doi.org/10.4324/9780203799178-5).

Vasilyan, S. (2017), Swinging on a Pendulum: Armenia in the Eurasian Economic Union and With the European Union, Problems of Post-Communism, 64(1), pp. 32-46. https://doi.org/10.1080/10758216.2016.1163230. 